Article

\title{
Iron-Catalyzed Conjugate Addition of Aryl Iodides onto Activated Alkenes under Air in Water
}

\author{
Chung-Min Huang ${ }^{\dagger}$, Wen-Sheng Peng ${ }^{\dagger}$, Ling-Jun Liu, Chien-Chi Wu and Fu-Yu Tsai ${ }^{*}$ (I) \\ Institute of Organic and Polymeric Materials, National Taipei University of Technology, 1, Sec. 3, Chung-Hsiao E. \\ Rd., Taipei 10608, Taiwan; gn00989189@hotmail.com (C.-M.H.); t107519006@ntut.edu.tw (W.-S.P.); \\ lingebubest@gmail.com (L.-J.L.); amywu0716@gmail.com (C.-C.W.) \\ * Correspondence: fuyutsai@ntut.edu.tw; Tel.: +886-2-2771-2171 (ext. 2437) \\ † These authors contributed equally.
}

Received: 29 September 2020; Accepted: 12 November 2020; Published: 13 November 2020

check for updates

\begin{abstract}
The combination of commercially available $\mathrm{FeCl}_{3} \cdot 6 \mathrm{H}_{2} \mathrm{O}$ with a water-soluble cationic 2,2'-bipyridyl catalytic system was found to enable the direct conjugate addition of aryl iodides onto activated alkenes, such as an $\alpha, \beta$-unsaturated ester and a ketone, in a weakly acidic aqueous solution. This operationally simple protocol was carried out at $80^{\circ} \mathrm{C}$ under air atmosphere in a potassium acetate-buffered aqueous solution for $12 \mathrm{~h}$ in the presence of $\mathrm{Zn}$ dust as a reductant to provide the desired 1,4-adducts in good yields.
\end{abstract}

Keywords: iron catalyst; water; conjugate addition; aryl iodide; activated alkene

\section{Introduction}

Transition-metal-catalyzed conjugate addition onto $\alpha, \beta$-unsaturated carbonyl compounds for the formation of $\mathrm{C}-\mathrm{C}$ bonds is one of the most promising and powerful methods in organic synthesis [1]. Conventionally, pre-formed stoichiometric organometallic compounds, such as organoboron, organotin, organozinc, and organosilicon (which are usually prepared from alkyl/aryl halides), are required as the nucleophilic reagents to couple with activated olefins under Co [2], Ni [3-7], Cu [8-10], Ru [11], $\mathrm{Rh}$ [12-40], Pd [41-63], and Ir [64,65] catalysis. Recently, Pd-based [66-69] and first transition series catalysts, such as $\mathrm{Co}$ [70-77], $\mathrm{Ni}$ [77-80], In/Cu [81], and Cu [82-86], for the conjugate addition of organic halides, triflates, or tosylates onto activated alkenes have been well-documented. The advantage of this protocol is that the pre-formed stoichiometric organometallic nucleophile is not required prior to the conjugate addition [87]. Typically, the transition-metal-catalyzed conjugate addition of organic halides onto activated olefins is conducted in hydrous organic solvents, where $\mathrm{H}_{2} \mathrm{O}$ is used to facilitate the protonolysis of the carbon-metal bond to afford the 1,4-adducts. There are only a few reports of these reactions performing in aqueous media [81-86]. Hence, the challenge remains to develop efficient conjugate addition reactions conducted in aqueous solutions to reduce the waste of organic solvents.

Based on the environmental and economic concerns, the use of iron-which is nontoxic and the cheapest transition metal-to catalyze 1,4-addition is highly desirable. Lipshutz reported that an Fe(II) salt can catalyze the reductive coupling of alkyl halides with either vinyl aromatics or heteroaromatics in an aqueous solution in the presence of a surfactant [88]. However, the iron-catalyzed conjugate addition of aryl halides onto activated olefins in water has not yet been explored. We previously found that the combination of commercially available $\mathrm{FeCl}_{3} \cdot 6 \mathrm{H}_{2} \mathrm{O}$ with a water-soluble cationic 2,2'-bipyridyl ligand, $\mathbf{L}$, as a catalytic system is able to catalyze the Sonogashira coupling of aryl iodides with terminal alkynes in water in the presence of excess $\mathrm{Zn}$ dust as a reductant [89]. Herein, we report that this iron catalytic system is capable of catalyzing the conjugate addition of aryl iodides onto activated alkenes in water under an air atmosphere by an operationally simple procedure (Scheme 1). 


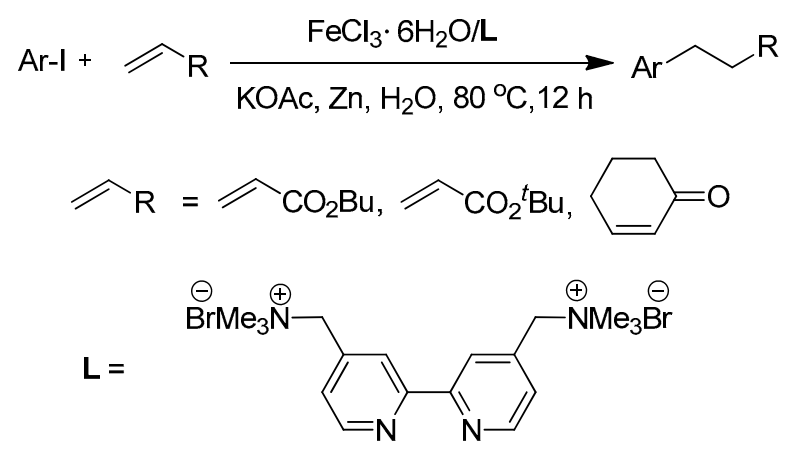

Scheme 1. Iron-catalyzed conjugate addition of aryl iodides onto activated alkenes.

\section{Results and Discussion}

To examine our initial idea for iron-catalyzed conjugate addition, iodobenzene $1 \mathrm{a}(1 \mathrm{mmol})$ and $n$-butyl acrylate $2 \mathrm{a}(4 \mathrm{mmol})$ were added into an $\mathrm{FeCl}_{3} \cdot 6 \mathrm{H}_{2} \mathrm{O} / \mathrm{L}$ aqueous solution $(10 \mathrm{~mol} \%$ in $3 \mathrm{~mL}$ $\left.\mathrm{H}_{2} \mathrm{O}\right)$ in the presence of $\mathrm{Zn}$ dust $(3 \mathrm{mmol})$ as a reductant at $80{ }^{\circ} \mathrm{C}$ for $12 \mathrm{~h}$; this produced butyl 3-phenylpropanoate, 3a, with a yield of only $22 \%$ (Table 1, Entry 1). We found that the $\mathrm{FeCl}_{3} \cdot 6 \mathrm{H}_{2} \mathrm{O} / \mathbf{L}$ aqueous solution was very acidic with a $\mathrm{pH}$ value of 1.8 ; hence, $\mathrm{Zn}$ may have reacted with the acid prior to reducing $\mathrm{Fe}(\mathrm{III})$. The addition of various amounts of potassium acetate (KOAc) to the aqueous phase led to the formation of a buffer solution with $\mathrm{pH}$ values between 5.0 and 5.8, which further increased the 1,4-adduct yields (Table 1, Entries 2-4). A more effective outcome was achieved when $2 \mathrm{mmol}$ KOAc was added to the aqueous solution (Table 1, Entry 3). Other, stronger inorganic bases were also screened, but these basic aqueous solutions produced low yields of 3a, presumably due to the high hydroxide concentration that retarded the protonolysis of the $\mathrm{C}-\mathrm{Fe}$ bond. This observation suggested that the $\mathrm{pH}$ control for this conjugate addition could be crucial (Table 1, Entries 5-7). Organic bases, such as $\mathrm{Bu}_{3} \mathrm{~N}$ and ${ }^{i} \mathrm{Pr}_{2} \mathrm{NEt}$, are known to promote the Pd-catalyzed conjugate addition of aryl iodides onto $\alpha, \beta$-unsaturated carbonyl compounds [66-68]; in our system, however, only a $47 \%$ yield of 3a was achieved when $\mathrm{Bu}_{3} \mathrm{~N}$ was used (Table 1, Entry 8). A higher concentration of $n$-butyl acrylate, $2 \mathbf{a}$, was necessary to provide higher product yields (Table 1, Entries 3, 9, and 10), which was also reported for the Ni-catalyzed reaction [78]. For the loading amount of $\mathrm{Zn}$, we observed that 3 equivalents of $\mathrm{Zn}$ against 1a resulted in the highest product yield of 3a (Table 1, Entries 3 and 11-13). In addition, 99.99\% pure $\mathrm{FeCl}_{3}$ was used to verify that this conjugate addition reaction was catalyzed by iron (Table 1 , Entry 14) [90]. Without the addition of $\mathbf{L}, \mathrm{FeCl}_{3} \cdot 6 \mathrm{H}_{2} \mathrm{O}$ could not catalyze this conjugate addition, leading to the recovery of $86 \%$ of $\mathbf{1 a}$ (Table 1, Entry 15). Furthermore, the replacement of $\mathbf{L}$ by neutral $2,2^{\prime}$-bipyridine gave rise to an inferior yield of $3 \mathbf{a}$ (Table 1, Entry 16). These results revealed that the water-soluble ligand in the reaction was indispensable. Similarly, no $3 \mathbf{a}$ was formed when the catalytic system was left out of the reaction (Table 1, Entry 17). Finally, a scaled-up reaction was performed employing $5 \mathrm{mmol}$ of 1 a to give $3 \mathbf{a}$ in $75 \%$ yield (Table 1, Entry 18). Unfortunately, an aryl bromide, such as bromobenzene, did not participate in this 1,4 addition; hence, bromobenzene remained intact (Table 1, Entry 19).

Since the reaction conditions had been optimized, a variety of aryl iodides (1) were further employed to evaluate the conjugate addition with 2a under the conditions listed in Table 1, Entry 3 , and the results are described in Table 2. A weakly electron-donating methyl group at the para position underwent a smooth reaction to produce $\mathbf{3 b}$ with a $74 \%$ yield (Table 2, Entry 1). However, this conjugate addition reaction did not proceed efficiently when a strong electron-donating group was added (Table 2, Entry 2). The low yield of 3c could be attributed to the methoxy group at the para position that decelerated the oxidative addition rate. Sterically congested aryl iodides, such as $\mathbf{1 d}$ and 1e, only slightly affected the reaction, producing $70 \%$ and $72 \%$ yields of $3 \mathbf{d}$ and $3 \mathbf{e}$, respectively (Table 2, Entries 3 and 4). 3-Substituted aryl and 1-naphthyl iodides, $\mathbf{1 f}-\mathbf{1 i}$, can also participate in this reaction, which produced the corresponding 1,4-adducts with yields between $75 \%$ and $79 \%$ (Table 2, 
Entries 5-8). For the electron-withdrawing groups $\mathbf{1} \mathbf{j}$ and $\mathbf{1} \mathbf{k}$, moderate product yields were recorded (Table 2, Entries 9 and 10). Because $\mathrm{Zn}$ was prone to insertion into the carbon-iodine bond in the presence of aryl iodides bearing an electron-withdrawing group at the para position, the formation of ArZnI was dominant when $\mathbf{1} \mathbf{j}$ and $\mathbf{1} \mathbf{k}$ were applied. Though arylzinc iodides could be temporarily stabilized by a certain surfactant in water [91], in our cases with $\mathbf{1} \mathbf{j}$ and $\mathbf{1} \mathbf{k}$, the swift protonolysis of the moisture-sensitive arylzinc iodides in weakly-acidic hot water resulted in the formation of the deiodinated by-products acetophenone and chlorobenzene, respectively $[72,89]$. The fast hydrolysis of ArZnX was further demonstrated using 3,5-dimethylphenylzinc chloride instead of using the iodide analogue, which gave rise to only $m$-xylene under the reaction conditions of Entry 7 in Table 2. The heteroaromatic 2-iodothiophene, 11, failed to provide the desired conjugate adduct, resulting in the recovery of $\mathbf{1 1}$ (Table 2, Entry 11). A similar outcome was also observed in the Pd nanoparticle-catalyzed 1,4-addition reaction [68].

To further expand the substrate scope, other $\alpha, \beta$-unsaturated carbonyl compounds, $\mathbf{2 b}$ and $\mathbf{2 c}$, were added to this reaction (Table 3 ). The conjugate addition of aryl iodides onto alkenes proceeded smoothly, producing the desired products in yields of 70-84\% (Table 3, Entries 1, 2, 4-11, and 13-18), except for the use of 4-iodoanisole 1c (Table 3, Entries 3 and 12). In contrast to 2-substituted aryl iodides, the steric hindrance on activated olefins inhibited the application of $2 \mathbf{d}$ and $\mathbf{2 e}$ in the conjugate addition reactions (Table 3, Entries 19 and 20).

Table 1. Iron-catalyzed conjugate addition of iodobenzene (1a) onto $n$-butyl acrylate (2a) a

\begin{tabular}{|c|c|c|c|c|c|}
\hline Entry & 2a (mmol) & Zn (mmol) & Base (mmol) & $\mathrm{pH}$ & Yield $(\%)^{b}$ \\
\hline 1 & 4 & 3 & - & 1.8 & 22 \\
\hline 2 & 4 & 3 & KOAc (1) & 5.0 & 74 \\
\hline 3 & 4 & 3 & KOAc (2) & 5.5 & 85 \\
\hline 4 & 4 & 3 & KOAc (3) & 5.8 & 80 \\
\hline 5 & 4 & 3 & $\mathrm{~K}_{2} \mathrm{CO}_{3}(2)$ & 11.5 & 40 \\
\hline 6 & 4 & 3 & $\mathrm{~K}_{3} \mathrm{PO}_{4}(2)$ & 13.5 & 35 \\
\hline 7 & 4 & 3 & $\mathrm{KOH}(2)$ & 15.4 & 23 \\
\hline 8 & 4 & 3 & $\mathrm{Bu}_{3} \mathrm{~N}(2)$ & 6.8 & 47 \\
\hline 9 & 3 & 3 & KOAc (2) & & 77 \\
\hline 10 & 2 & 3 & KOAc (2) & & 52 \\
\hline 11 & 4 & 2.5 & KOAc (2) & & 74 \\
\hline 12 & 4 & 2 & KOAc (2) & & 61 \\
\hline 13 & 4 & 0 & KOAc (2) & & 0 \\
\hline $14^{c}$ & 4 & 3 & KOAc (2) & & 86 \\
\hline $15^{\mathrm{d}}$ & 4 & 3 & KOAc (2) & & 0 \\
\hline $16^{\mathrm{e}}$ & 4 & 3 & KOAc (2) & & 12 \\
\hline $17^{\mathrm{f}}$ & 4 & 3 & KOAc (2) & & 0 \\
\hline $18^{g}$ & 20 & 15 & KOAc (10) & & 75 \\
\hline $19^{\mathrm{h}}$ & 4 & 3 & KOAc (2) & & 0 \\
\hline
\end{tabular}

a Reaction conditions: 1a $(1 \mathrm{mmol}), \mathbf{2 a}, \mathrm{Zn}$, base, $\mathrm{FeCl}_{3} \cdot 6 \mathrm{H}_{2} \mathrm{O} / \mathbf{L}(10 \mathrm{~mol} \%)$, and $\mathrm{H}_{2} \mathrm{O}(3 \mathrm{~mL})$ at $80{ }^{\circ} \mathrm{C}$ for $12 \mathrm{~h}$. b Isolated yields. c $99.99 \%$ pure $\mathrm{FeCl}_{3}$ was used. ${ }^{\mathrm{d}}$ In the absence of ligand $\mathbf{L}$. e Neutral 2,2'-bipyridine was used as the ligand. ${ }^{\mathrm{f}}$ In the absence of $\mathrm{FeCl}_{3} \cdot 6 \mathrm{H}_{2} \mathrm{O} / \mathbf{L} .{ }^{\mathrm{g}} 5 \mathrm{mmol}$ of $\mathbf{1 a}$ was used. ${ }^{\mathrm{h}}$ Iodobenzene 1a was replaced by bromobenzene.

To elucidate the reaction mechanism, the reaction conditions listed in Table 1, Entry 3 were performed in the presence of a $1 \mathrm{mmol}$ radical scavenger, (2,2,6,6-tetramethylpiperidin-1yl)oxyl-TEMPO. We found that the presence of TEMPO in the reaction did not suppress the conjugate addition, which still produced 3a in an identical yield to that in Table 1, Entry 3; the radical pathway for this conjugate addition is therefore unlikely. In addition, $>98 \%$ deuterium at the $\alpha$-carbon to the product was observed when the reaction was conducted in $\mathrm{D}_{2} \mathrm{O}$ (see the Supporting Information for the ${ }^{1} \mathrm{H}$ and ${ }^{13} \mathrm{C}$ NMR spectra). This result implied that the $\mathrm{C}_{\mathrm{sp}}{ }^{3}$-Fe bond was hydrolyzed by $\mathrm{H}_{2} \mathrm{O}$ to release the final product in the reaction. Following the above results, although the radical pathway cannot be completely ruled out, a similar mechanism to those in first-series transition-metal-catalyzed conjugate 
additions of aryl/alkyl halides onto $\alpha, \beta$-unsaturated carbonyl compounds has been proposed [71,72,78]. As shown in Scheme 2, Fe(III) was first reduced by Zn dust, followed by the oxidative addition of an aryl iodide, to deliver aryl iron(III) intermediate $\mathbf{A}$. The coordination of an activated olefin to the $\mathrm{Fe}(\mathrm{III})$ center and a subsequent migratory insertion provided intermediate $\mathbf{B}$. The protonolysis of $\mathbf{B}$ by water afforded the conjugated addition product along with Fe(III). Then, reduction of Fe(III) by Zn regenerated $\mathrm{Fe}(\mathrm{I})$ for the next catalytic cycle.

Table 2. Iron-catalyzed conjugate addition of aryl iodides (1) onto $n$-butyl acrylate (2a) ${ }^{\text {a }}$.

\begin{tabular}{|c|c|c|c|}
\hline Entry & Aryl Iodide & Product & Yield (\%) ${ }^{b}$ \\
\hline 1 & & & 74 \\
\hline 2 & & $3 c$ & 44 \\
\hline 3 & & & 70 \\
\hline 4 & & & 72 \\
\hline 5 & & & 75 \\
\hline 6 & & $3 g$ & 79 \\
\hline 7 & & & 78 \\
\hline 8 & & & 75 \\
\hline 9 & & & 40 \\
\hline 10 & & & 52 \\
\hline 11 & & & 0 \\
\hline
\end{tabular}

a Reaction conditions: 1 (1 mmol), 2 a $(4 \mathrm{mmol}), \mathrm{Zn}(3 \mathrm{mmol}), \mathrm{KOAc}(2 \mathrm{mmol}), \mathrm{FeCl}_{3} \cdot 6 \mathrm{H}_{2} \mathrm{O} / \mathbf{L}(10 \mathrm{~mol} \%)$, and $\mathrm{H}_{2} \mathrm{O}$ $(3 \mathrm{~mL})$ at $80^{\circ} \mathrm{C}$ for $12 \mathrm{~h} .{ }^{\mathrm{b}}$ Isolated yields. 
Table 3. Iron-catalyzed conjugate addition of aryl iodides (1) onto activated alkenes (2) ${ }^{\text {a }}$.

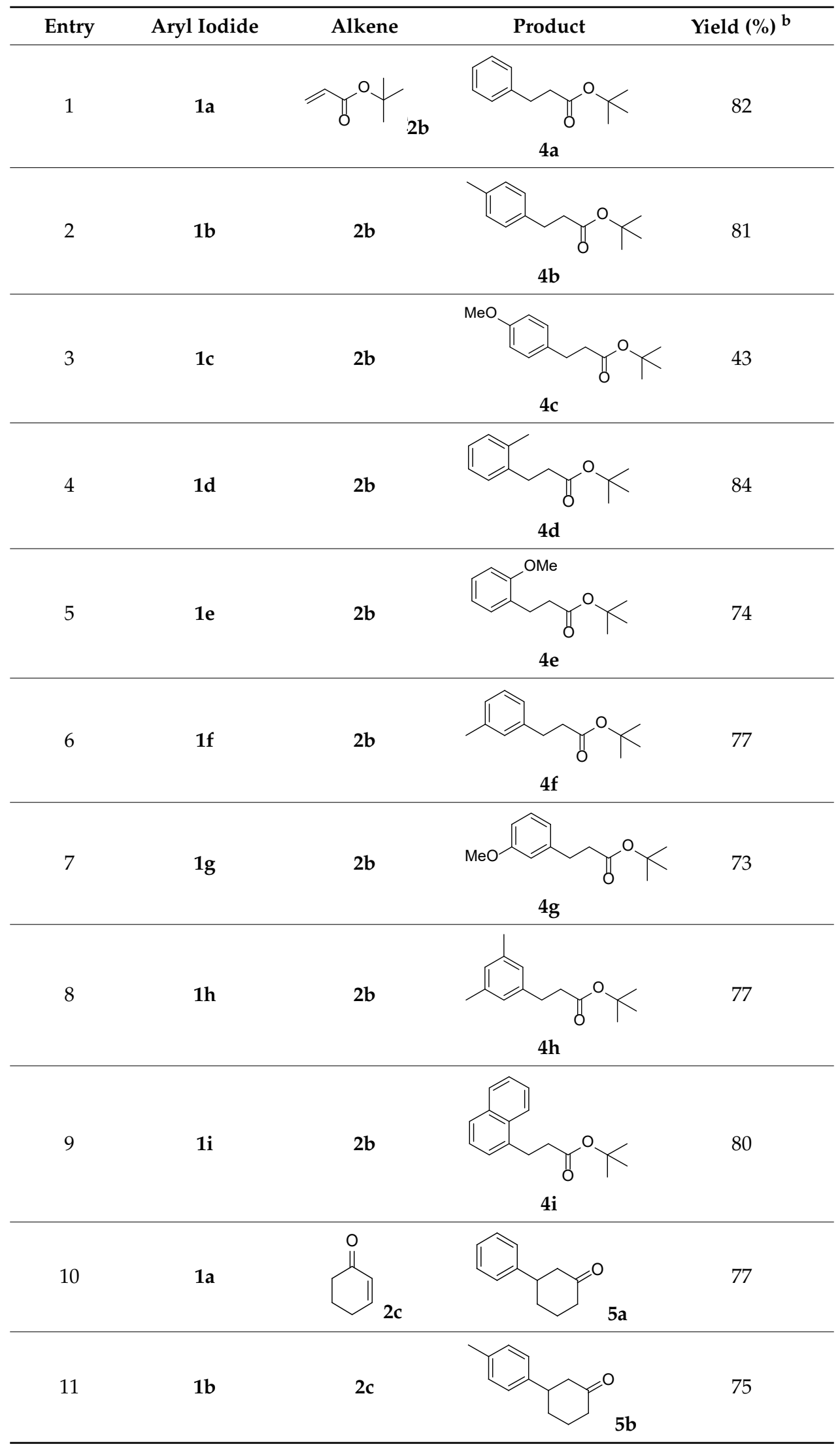


Table 3. Cont.

\begin{tabular}{|c|c|c|c|c|}
\hline Entry & Aryl Iodide & Alkene & Product & Yield (\%) ${ }^{b}$ \\
\hline 12 & $1 c$ & $2 c$ & & 55 \\
\hline 13 & 1d & $2 c$ & & 73 \\
\hline 14 & 1e & $2 c$ & & 74 \\
\hline 15 & $1 f$ & $2 c$ & & 70 \\
\hline 16 & $1 \mathrm{~g}$ & $2 c$ & & 72 \\
\hline 17 & 1h & $2 c$ & & 81 \\
\hline 18 & $\mathbf{1 i}$ & $2 c$ & & 78 \\
\hline 19 & 1a & & & 0 \\
\hline 20 & $1 \mathrm{a}$ & & & 0 \\
\hline
\end{tabular}

a Reaction conditions: $1(1 \mathrm{mmol}), 2(4 \mathrm{mmol}), \mathrm{Zn}(3 \mathrm{mmol}), \mathrm{KOAc}(2 \mathrm{mmol}), \mathrm{FeCl}_{3} \cdot 6 \mathrm{H}_{2} \mathrm{O} / \mathrm{L}(10 \mathrm{~mol} \%)$, and $\mathrm{H}_{2} \mathrm{O}$ $(3 \mathrm{~mL})$ at $80{ }^{\circ} \mathrm{C}$ for $12 \mathrm{~h} .{ }^{\mathrm{b}}$ Isolated yields. 


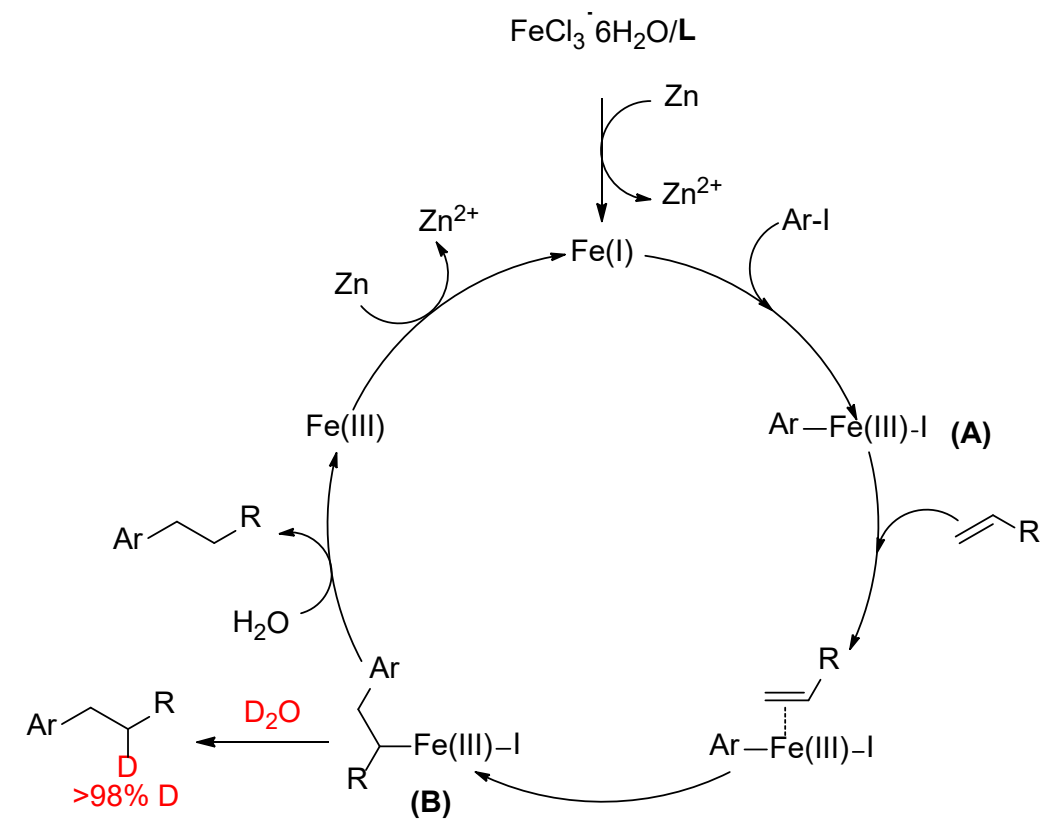

Scheme 2. Proposed mechanism for the conjugated addition.

\section{Materials and Methods}

\subsection{General Methods}

Aryl iodides, butyl acrylates, 2-cyclohexen-1-one, $\mathrm{Bu}_{3} \mathrm{~N}, \mathrm{D}_{2} \mathrm{O}$, and $\mathrm{FeCl}_{3} \cdot 6 \mathrm{H}_{2} \mathrm{O}$ were acquired from Acros Organics. $\mathrm{KOAc}, \mathrm{K}_{2} \mathrm{CO}_{3}, \mathrm{~K}_{3} \mathrm{PO}_{4}$, and $\mathrm{KOH}$ were purchased from SHOWA Chemical Co. Ltd (Tokyo, Japan). The cationic 2,2'-bipyridyl ligand (L) was prepared according to the known procedure [92,93]. NMR spectra were recorded in $\mathrm{CDCl}_{3}$ on a Bruker Biospin AG $300 \mathrm{NMR}$ spectrometer (Bruker Co., Faellanden, Switzerland) at $25^{\circ} \mathrm{C}$, where the chemical shifts ( $\delta$ in ppm) were established

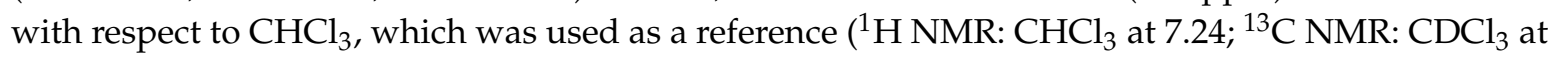
77.0). High-resolution mass spectrometry (HRMS) was performed on a JEOL AccuTOF GCx-plus and SHIMADZU QP2020 at the Instrument Center Service, Ministry of Science and Technology of Taiwan. The spectral data of all conjugate adducts can be found in the Supporting Information.

\subsection{Typical Procedure for the Conjugate Addition of Aryl Iodides onto Activated Olefins}

A $20 \mathrm{~mL}$ cylinder reactor was charged with $\mathrm{FeCl}_{3} \cdot 6 \mathrm{H}_{2} \mathrm{O}(0.1 \mathrm{mmol})$ and cationic 2,2'-bipyridyl ligand $\mathrm{L}\left(0.1 \mathrm{mmol}\right.$ in $3 \mathrm{~mL}$ of $\left.\mathrm{H}_{2} \mathrm{O}\right)$. After stirring this solution at room temperature for $30 \mathrm{~min}, \mathrm{KOAc}$ $(2.0 \mathrm{mmol})$ was then added to the wine-red solution, which stirred for an additional $5 \mathrm{~min}$. Aryl iodide $(1.0 \mathrm{mmol})$, activated alkene $(4.0 \mathrm{mmol})$, and $\mathrm{Zn}$ dust $(3.0 \mathrm{mmol})$ were added in sequence, and the reaction mixture was then stirred at $80^{\circ} \mathrm{C}$ under air atmosphere for $12 \mathrm{~h}$. After cooling the reaction to room temperature, $3 \mathrm{~N} \mathrm{HCl}(2 \mathrm{~mL})$ was added into the aqueous solution and extracted with ethyl acetate $(3 \times 5 \mathrm{~mL})$; the combined organic phase was then dried over $\mathrm{MgSO}_{4}$. The solvent was removed under reduced pressure, and the residue was purified by column chromatography on silica gel to give the desired product.

\section{Conclusions}

In conclusion, we developed an environmentally friendly method for the conjugate addition of aryl iodides onto activated alkenes catalyzed by a green catalytic system in water under an air atmosphere. Several activated olefins, such as an $\alpha, \beta$-unsaturated ester and a ketone, can be applied to form 1,4-adducts in good-to-high yields. Nontoxic and cheap iron is used as the catalyst, and neither organometallic reagents nor organic solvents are required in this reaction, rendering this procedure 
sustainable. Further development of this green catalytic system for other reactions in water under ambient conditions is now underway in our laboratory.

Supplementary Materials: The following are available online at http://www.mdpi.com/2073-4344/10/11/1320/s1: the spectral data and copies of ${ }^{1} \mathrm{H}$ - and ${ }^{13} \mathrm{C}-\mathrm{NMR}$ spectra of all conjugate addition products.

Author Contributions: C.-M.H., W.-S.P., L.-J.L., and F.-Y.T. conceived, designed, and executed the experiments and analyzed the data; W.-S.P. and C.-C.W. performed the NMR measurements; F.-Y.T. wrote the paper. All authors have read and agreed to the published version of the manuscript.

Funding: This research was financially supported by the Ministry of Science and Technology of Taiwan (MOST 108-2113-M-027-003).

Acknowledgments: We thank the Instrument Center Service at National Cheng Kung University, Ministry of Science and Technology of Taiwan for high-resolution mass spectrometry measurement.

Conflicts of Interest: The authors declare no conflict of interest.

\section{References}

1. Perlmutter, P. Conjugate Addition Reactions in Organic Synthesis; Pergamon Press: Oxford, UK, 1992.

2. Chen, M.-H.; Mannathan, S.; Lin, P.-S.; Cheng, C.-H. Cobalt(II)-catalyzed 1,4-addition of organoboronic acids to activated alkenes: An application to highly cis-stereoselective synthesis of aminoindane carboxylic acid derivatives. Chem. Eur. J. 2012, 18, 14918-14922. [CrossRef] [PubMed]

3. Shirakawa, E.; Yashuhara, Y.; Hayashi, T. Nickel-catalyzed conjugate addition of arylboron reagents to $\alpha, \beta$-unsaturated carbonyl compounds with the aid of a catalytic amount of an alkyne. Chem. Lett. 2006, 35, 768-769. [CrossRef]

4. Sieber, J.D.; Liu, S.; Morken, J.P. Catalytic conjugate addition of allyl groups to styryl-activated enones. J. Am. Chem. Soc. 2007, 129, 2214-2215. [CrossRef] [PubMed]

5. Hirano, K.; Yorimitsu, H.; Oshima, K. Nickel-catalyzed 1,4-addition of trialkylboranes to $\alpha, \beta$-unsaturated esters: Dramatic enhancement by addition of methanol. Org. Lett. 2007, 9, 1541-1544. [CrossRef] [PubMed]

6. Meng, J.-J.; Gao, M.; Dong, M.; Wei, Y.-P.; Zhang, W.-Q. Catalyzation of 1,4-additions of arylboronic acids to $\alpha, \beta$-unsaturated substrates using nickel(I) complexes. Tetrahedron Lett. 2014, 55, 2107-2109. [CrossRef]

7. Chen, W.; Sun, L.; Huang, X.; Wang, J.; Peng, Y.; Song, G. Ligand-free nickel-catalysed 1,4-addition of arylboronic acids to $\alpha, \beta$-unsaturated carbonyl compounds. Adv. Synth. Catal. 2015, 357, 1474-1482. [CrossRef]

8. Takatsu, K.; Shintani, R.; Hayashi, T. Copper-catalyzed 1,4-addition of organoboronates to alkylidene cyanoacetates: Mechanistic insight and application to asymmetric catalysis. Angew. Chem. Int. Ed. 2011, 50, 5548-5552. [CrossRef]

9. Yoshida, M.; Ohmiya, H.; Sawamura, M. Enantioselective conjugate addition of alkylboranes catalyzed by a copper-N-heterocyclic carbene complex. J. Am. Chem. Soc. 2012, 134, 11896-11899. [CrossRef]

10. Liao, Y.-X.; Hu, Q.-S. CuCl/bipyridine-catalyzed addition reactions of arylboroxines with aldehydes, $\alpha, \beta$-unsaturated ketones, and N-tosyl aldimines. J. Org. Chem. 2011, 76, 7602-7607. [CrossRef]

11. Zhang, L.; Xie, X.; Peng, Z.; Fu, L.; Zhang, Z. Ru-catalyzed 1,4-addition of arylboronic acids to acrylic acid derivatives in the presence of phenols. Chem. Commun. 2013, 49, 8797-8799. [CrossRef]

12. Hayashi, T.; Yamasaki, K. Rhodium-catalyzed asymmetric 1,4-addition and its related asymmetric reactions. Chem. Rev. 2003, 103, 2829-2844. [CrossRef] [PubMed]

13. Zhao, G.-Z.; Foster, D.; Sipos, G.; Gao, P.; Skelton, B.W.; Sobolev, A.N.; Dorta, R. Electronic and steric tuning of an atropisomeric disulfoxide ligand motif and its use in the $\mathrm{Rh}(\mathrm{I})$-catalyzed addition reactions of boronic acids to a wide range of acceptors. J. Org. Chem. 2018, 83, 9741-9755. [CrossRef] [PubMed]

14. Kamikawa, K.; Tseng, Y.-Y.; Jian, J.-H.; Takahashi, T.; Ogasawara, M. Planar-chiral phosphine-olefin ligands exploiting a (cyclopentadienyl)manganese(I) scaffold to achieve high robustness and high enantioselectivity. J. Am. Chem. Soc. 2017, 139, 1545-1553. [CrossRef] [PubMed]

15. Lee, A.; Kim, H. Chiral bicyclic bridgehead phosphoramidite (briphos) ligands for asymmetric rhodium-catalyzed 1,2- and 1,4-addition. J. Org. Chem. 2016, 81, 3520-3527. [CrossRef] 
16. Ogasawara, M.; Tseng, Y.-Y.; Arae, S.; Morita, T.; Nakaya, T.; Wu, W.-Y.; Takahashi, T.; Kamikawa, K. Phosphine-olefin ligands based on a planar-chiral ( $\pi$-arene)chromium scaffold: Design, synthesis, and application in asymmetric catalysis. J. Am. Chem. Soc. 2014, 136, 9377-9384. [CrossRef]

17. Korenaga, T.; Ko, A.; Shimada, K. Low-temperature Rh-catalyzed asymmetric 1,4-addition of arylboronic acids to $\alpha, \beta$-unsaturated carbonyl compounds. J. Org. Chem. 2013, 78, 9975-9980. [CrossRef]

18. Liu, C.-C.; Janmanchi, D.; Chen, C.-C.; Wu, H.-L. Expanding the $C_{1}$-symmetric bicyclo[2.2.1]heptadiene ligand family: Highly enantioselective synthesis of cyclic $\beta$-aryl-substituted carbonyl compounds. Eur. J. Org. Chem. 2012, 2012, 2503-2507. [CrossRef]

19. Thaler, T.; Guo, L.-N.; Steib, A.K.; Raducan, M.; Karaghiosoff, K.; Mayer, P.; Knochel, P. Sulfoxide-alkene hybrids: A new class of chiral ligands for the Hayashi-Miyaura reaction. Org. Lett. 2011, 13, 3182-3185. [CrossRef]

20. Xue, F.; Li, X.; Wan, B. A class of benzene backbone-based olefin-sulfoxide ligands for Rh-catalyzed enantioselective addition of arylboronic acids to enones. J. Org. Chem. 2011, 76, 7256-7262. [CrossRef]

21. Berhal, F.; Wu, Z.; Genet, J.-P.; Ayad, T.; Ratovelomanana-Vidal, V. Rh-catalyzed asymmetric 1,4-addition of arylboronic acids to $\alpha, \beta$-unsaturated ketones with DIFLUORPHOS and SYNPHOS analogues. J. Org. Chem. 2011, 76, 6320-6326. [CrossRef]

22. Le Boucher d'Herouville, F.; Millet, A.; Scalone, M.; Michelet, V. Room-temperature Rh-catalyzed asymmetric 1,4-addition of arylboronic acids to maleimides and enones in the presence of $\mathrm{CF}_{3}$-substituted MeOBIPHEP analogues. J. Org. Chem. 2011, 76, 6925-6930. [CrossRef] [PubMed]

23. Duan, W.-L.; Iwamura, H.; Shintani, R.; Hayashi, T. Chiral phosphine-olefin ligands in the rhodium-catalyzed asymmetric 1,4-addition reactions. J. Am. Chem. Soc. 2007, 129, 2130-2138. [CrossRef] [PubMed]

24. Shintani, R.; Yamagami, T.; Kimura, T.; Hayashi, T. Asymmetric synthesis of 2-aryl-2,3-dihydro-4-quinolones by rhodium-catalyzed 1,4-addition of arylzinc reagents in the presence of chlorotrimethylsilane. Org. Lett. 2005, 7, 5317-5319. [CrossRef]

25. Chen, G.; Tokunaga, N.; Hayashi, T. Rhodium-catalyzed asymmetric 1,4-addition of arylboronic acids to coumarins: Asymmetric synthesis of (R)-tolterodine. Org. Lett. 2005, 7, 2285-2288. [CrossRef] [PubMed]

26. Shintani, R.; Tokunaga, N.; Doi, H.; Hayashi, T. A new entry of nucleophiles in rhodium-catalyzed asymmetric 1,4-addition reactions: Addition of organozinc reagents for the synthesis of 2-aryl-4-piperidones. J. Am. Chem. Soc. 2004, 126, 6240-6241. [CrossRef] [PubMed]

27. Oi, S.; Moro, M.; Ito, H.; Honma, Y.; Miyano, S. Rhodium-catalyzed conjugate addition of aryl- and alkenyl-stannanes to $\alpha, \beta$-unsaturated carbonyl compounds. Tetrahedron 2002, 58, 91-97. [CrossRef]

28. Oi, S.; Honma, Y.; Inoue, Y. Conjugate addition of organosiloxanes to $\alpha, \beta$-unsaturated carbonyl compounds catalyzed by a cationic rhodium complex. Org. Lett. 2002, 4, 667-669. [CrossRef] [PubMed]

29. Mori, A.; Danda, Y.; Fujii, T.; Hirabayashi, K.; Osakada, K. Hydroxorhodium complex-catalyzed carbon-carbon bond-forming reactions of silanediols with $\alpha, \beta$-unsaturated carbonyl compounds. Mizoroki-Heck-type reaction vs conjugate addition. J. Am. Chem. Soc. 2001, 123, 10774-10775. [CrossRef]

30. Takaya, Y.; Ogasawara, M.; Hayashi, T.; Sakai, M.; Miyaura, N. Rhodium-catalyzed asymmetric 1,4-addition of aryl- and alkenylboronic acids to enones. J. Am. Chem. Soc. 1998, 120, 5579-5580. [CrossRef]

31. Ruiz-Botella, S.; Peris, E. Immobilization of pyrene-adorned N-heterocyclic carbene complexes of rhodium (I) on reduced graphene oxide and study of catalytic activity. ChemCatChem 2018, 10, 1874-1881. [CrossRef]

32. Mühlhäuser, T.; Savin, A.; Frey, W.; Baro, A.; Schneider, A.J.; Döteberg, H.-G.; Bauer, F.; Köhn, A.; Laschat, S. Role of regioisomeric bicyclo[3.3.0]octa-2,5-diene ligands in Rh catalysis: Synthesis, structural analysis, theoretical study, and application in asymmetric 1,2- and 1,4-additions. J. Org. Chem. 2017, 82, 13468-13480. [CrossRef] [PubMed]

33. Melcher, M.-C.; da Silva, B.R.A.; Ivšić, T.; Strand, D. Chiral discrimination in rhodium(I) catalysis by 2,5-disubstituted 1,3a,4,6a-tetrahydropenatalene ligands-more than just a twist of the Olefins? ACS Omega 2018, 3, 3622-3630. [CrossRef] [PubMed]

34. Ramasamy, B.; Prakasham, A.P.; Gangwar, M.K.; Ghosh, P. 1,4-Conjugate addition of aryl boronic acids on cyclohexenone as catalyzed by rhodium(I) complexes of $C_{2}$-symmetric bioxazoline fused $\mathrm{N}$-heterocyclic carbenes. ChemistrySelect 2019, 4, 8526-8533. [CrossRef]

35. Motokura, K.; Hashiguchi, K.; Maeda, K.; Nambo, M.; Manaka, Y.; Chun, W.-J. Rh-catalyzed 1,4-addition reactions of arylboronic acids accelerated by co-immobilized tertiary amine in silica mesopores. Mol. Catal. 2019, 472, 1-9. [CrossRef] 
36. Borrego, L.G.; Recio, R.; Álvarez, E.; Sánchez-Coronilla, A.; Khiar, N.; Fernández, I. Steric tuning of sulfinamide/sulfoxides as chiral ligands with $C_{1}$, pseudo-meso, and pseudo- $C_{2}$ symmetries: Application in rhodium(I)-mediated arylation. Org. Lett. 2019, 21, 6513-6518. [CrossRef]

37. Fan, C.; Wu, Q.; Zhu, C.; Wu, X.; Li, Y.; Luo, Y.; He, J.-B. Enantioselective conjugate addition of aryl halides and triflates to electron-deficient olefins via nickel- and rhodium-catalyzed sequential relay reactions. Org. Lett. 2019, 21, 8888-8892. [CrossRef]

38. Pecchioli, T.; Christmann, M. Synthesis of highly enantioenriched propelladienes and their application as ligands in asymmetric Rh-catalyzed 1,4-additions. Org. Lett. 2018, 20, 5256-5259. [CrossRef]

39. Nikol, A.; Zhang, Z.; Chelouan, A.; Falivene, L.; Cavallo, L.; Herrera, A.; Heinemann, F.W.; Escalona, A.; Frieß, S.; Grasruck, A.; et al. Tricyclic sulfoxide-alkene hybrid ligands for chiral Rh(I) complexes: The "matched" diastereomer catalyzes asymmetric C-C bond formations. Organometallics 2020, 39, 1348-1359. [CrossRef]

40. Kirchhof, M.; Gugeler, K.; Fischer, F.R.; Nowakowski, M.; Bauer, A.; Alvarez-Barcia, S.; Abitaev, K.; Schnierle, M.; Qawasmi, Y.; Frey, W.; et al. Experimental and theoretical Sstudy on the role of monomeric vs dimeric rhodium oxazolidinone norbornadiene complexes in catalytic asymmetric 1,2- and 1,4-additions. Organometallics 2020, 39, 3131-3145. [CrossRef]

41. Hamasaka, G.; Muto, T.; Andoh, Y.; Fujimoto, K.; Kato, K.; Takata, M.; Okazaki, S.; Uozumi, Y. Detailed structural analysis of a self-assembled vesicular amphiphilic NCN-pincer palladium complex by using wide-angle X-ray scattering and molecular dynamics calculations. Chem. Eur. J. 2017, 23, 1291-1298. [CrossRef]

42. Tamura, M.; Ogata, H.; Ishida, Y.; Takahashi, Y. Design and synthesis of chiral 1,10-phenanthroline ligand, and application in palladium catalyzed asymmetric 1,4-addition reactions. Tetrahedron Lett. 2017, 58, 3808-3813. [CrossRef]

43. de Gracia Retamosa, M.; Álvarez-Casao, Y.; Matador, E.; Gómez, Á.; Monge, D.; Fernández, R.; Lassaletta, J.M. Pyridine-hydrazone ligands in asymmetric palladium-catalyzed 1,4- and 1,6-additions of arylboronic acids to cyclic (di)enones. Adv. Synth. Catal. 2019, 361, 176-184. [CrossRef]

44. Shimizu, M.; Yamamoto, T. 9-(Diphenylphosphino)anthracene-based phosphapalladacycle catalyzed conjugate addition of arylboronic acids to electron-deficient alkenes. Tetrahedron Lett. 2020, 61, 152257. [CrossRef]

45. Gerten, A.L.; Stanley, L.M. Palladium-catalyzed conjugate addition of arylboronic acids to 2-substituted chromones in aqueous media. Tetrahedron Lett. 2016, 57, 5460-5463. [CrossRef]

46. Shockley, S.E.; Holder, J.C.; Stoltz, B.M. Palladium-catalyzed asymmetric conjugate addition of arylboronic acids to $\alpha, \beta$-unsaturated cyclic electrophiles. Org. Process Res. Dev. 2015, 19, 974-981. [CrossRef]

47. Lan, Y.; Houk, K.N. Mechanism of the palladium-catalyzed addition of arylboronic acids to enones: A computational study. J. Org. Chem. 2011, 76, 4905-4909. [CrossRef]

48. Tomás-Mendivil, E.; Díez, J.; Cadierno, V. Conjugate addition of arylboronic acids to $\alpha, \beta$-unsaturated carbonyl compounds in aqueous medium using $\mathrm{Pd}(\mathrm{II})$ complexes with dihydroxy-2,2'-bipyridine ligands: Homogeneous or heterogeneous nano-catalysis? Catal. Sci. Technol. 2011, 1, 1605-1615. [CrossRef]

49. Huang, S.-H.; Wu, T.-M.; Tsai, F.-Y. pH-dependent conjugate addition of arylboronic acids to $\alpha, \beta$-unsaturated enones catalyzed by a reusable palladium(II)/cationic 2,2'-bipyridyl system in water under air. Appl. Organometal. Chem. 2010, 24, 619-624. [CrossRef]

50. Nishikata, T.; Kiyomura, S.; Yamamoto, Y.; Miyaura, N. Asymmetric 1,4-addition of arylboronic acid to $\alpha, \beta$-unsaturated esters catalyzed by dicationic palladium(II)-chiraphos complex for short-step synthesis of SmithKline Beecham's endothelin receptor antagonist. Synlett 2008, 2008, 2487-2488. [CrossRef]

51. Nishikata, T.; Yamamoto, Y.; Miyaura, N. Palladium(II)-catalyzed 1,4-addition of arylboronic acids to $\beta$-arylenals for enantioselective syntheses of 3,3-diarylalkanals: A short synthesis of (+)-(R)-CDP 840. Tetrahedron Lett. 2007, 48, 4007-4010. [CrossRef]

52. He, P.; Lu, Y.; Dong, C.-G.; Hu, Q.-S. Anionic four-electron donor-based palladacycles as catalysts for addition reactions of arylboronic acids with $\alpha, \beta$-unsaturated ketones, aldehydes, and $\alpha$-ketoesters. Org. Lett. 2007, 9, 343-346. [CrossRef] [PubMed]

53. Gini, F.; Hessen, B.; Feringa, B.L.; Minnaard, A.J. Enantioselective palladium-catalysed conjugate addition of arylsiloxanes. Chem. Commun. 2007, 710-712. [CrossRef] [PubMed] 
54. Nishikata, T.; Yamamoto, Y.; Miyaura, N. Palladium(II)-catalyzed 1,4-addition of arylboronic acids to $\beta$-arylenones enantioselective synthesis of 4-aryl-4H-chromenes. Adv. Synth. Catal. 2007, 349, 1759-1764. [CrossRef]

55. Yamamoto, T.; Iizuka, M.; Ohta, T.; Ito, Y. Palladium catalyzed conjugate 1,4-addition of organoboronic acids to $\alpha, \beta$-unsaturated ketones. Chem. Lett. 2006, 35, 198-199. [CrossRef]

56. Gini, F.; Hessen, B.; Minnaard, A.J. Palladium-catalyzed enantioselective conjugate addition of arylboronic acids. Org. Lett. 2005, 7, 5309-5312. [CrossRef] [PubMed]

57. Lu, X.; Lin, S. Pd(II)-bipyridine catalyzed conjugate addition of arylboronic acid to a, $\beta$-unsaturated carbonyl compounds. J. Org. Chem. 2005, 70, 9651-9653. [CrossRef] [PubMed]

58. Nishikata, T.; Yamamoto, Y.; Miyaura, N. Asymmetric 1,4-addition of potassium aryltrifluoroborates $\left[\mathrm{ArBF}_{3}\right] \mathrm{K}$ to enones catalyzed by dicationic palladium(II) complexes. Chem. Lett. 2005, 34, 720-721. [CrossRef]

59. Nishikata, T.; Yamamoto, Y.; Miyaura, N. 1,4-Addition of arylboronic acids and arylsiloxanes to $\alpha, \beta$-unsaturated carbonyl compounds via transmetalation to dicationic palladium(II) complexes. Organometallics 2004, 23, 4317-4324. [CrossRef]

60. Nishikata, T.; Yamamoto, Y.; Miyaura, N. Conjugate addition of aryl boronic acids to enones catalyzed by cationic palladium(II)-phosphane complexes. Angew. Chem. Int. Ed. 2003, 42, 2768-2770. [CrossRef]

61. Ohe, T.; Wakita, T.; Motofusa, S.-I.; Cho, C.-S.; Ohe, K.; Uemura, S. Palladium(II)-catalyzed Michael-type addition reactions using aryltin compounds. Bull. Chem. Soc. Jpn. 2000, 73, 2149-2155. [CrossRef]

62. Denmark, S.E.; Amishiro, N. Palladium-catalyzed conjugate addition of organosiloxanes to $\alpha, \beta$-unsaturated carbonyl compounds and nitroalkenes. J. Org. Chem. 2003, 68, 6997-7003. [CrossRef] [PubMed]

63. Nishikata, T.; Yamamoto, Y.; Miyaura, N. 1,4-Addition of arylsiloxanes to enones catalyzed by dicationic palladium(II) complexes in aqueous media. Chem. Lett. 2003, 32, 752-753. [CrossRef]

64. Koike, T.; Du, X.; Sanada, T.; Danda, Y.; Mori, A. Iridium-catalyzed Mizoroki-Heck-type reaction of organosilicon reagents. Angew. Chem. Int. Ed. 2003, 42, 89-92. [CrossRef] [PubMed]

65. Fei, F.; Lu, T.; Yang, C.-F.; Chen, X.-T.; Xue, Z.-L. Synthesis, structures, and catalytic properties of dinuclear iridium(I) complexes with a hexadentate macrocyclic diamine tetracarbene ligand. Eur. J. Inorg. Chem. 2018, 2018, 1595-1602. [CrossRef]

66. Gottumukkala, A.L.; de Vries, J.G.; Minnaard, A.J. Pd-NHC catalyzed conjugate addition versus the Mizoroki-Heck reaction. Chem. Eur. J. 2011, 17, 3091-3095. [CrossRef]

67. Mannathan, S.; Raoufmoghaddam, S.; Reek, J.N.H.; de Vries, J.G.; Minnaard, A.J. Palladium(II) acetate catalyzed reductive Heck reaction of enones; a practical approach. ChemCatChem 2015, 7, 3923-3927. [CrossRef]

68. Parveen, N.; Saha, R.; Sekar, G. Stable and reusable palladium nanoparticles-catalyzed conjugate addition of aryl iodides to enones: Route to reductive Heck products. Adv. Synth. Catal. 2017, 359, 3741-3751. [CrossRef]

69. Yang, W.; Ling, B.; Hu, B.; Yin, H.; Mao, J.; Walsh, P.J. Synergistic N-heterocyclic carbene/palladium-catalyzed umpolung 1,4-addition of aryl iodides to enals. Angew. Chem. Int. Ed. 2020, 59, 161-166. [CrossRef]

70. Gomes, P.; Gosmini, C.; Nédélec, J.-Y.; Périchon, J. Cobalt bromide as catalyst in electrochemical addition of aryl halides onto activated olefins. Tetrahedron Lett. 2000, 41, 3385-3388. [CrossRef]

71. Shukla, P.; Hsu, Y.-C.; Cheng, C.-H. Cobalt-catalyzed reductive coupling of saturated alkyl halides with activated alkenes. J. Org. Chem. 2006, 71, 655-658. [CrossRef]

72. Amatore, M.; Gosmini, C.; Périchon, J. $\mathrm{CoBr}_{2}$ (Bpy): An efficient catalyst for the direct conjugate addition of aryl halides or triflates onto activated olefins. J. Org. Chem. 2006, 71, 6130-6134. [CrossRef] [PubMed]

73. Hsieh, J.-C.; Chu, Y.-H.; Muralirajan, K.; Cheng, C.-H. A simple route to 1,4-addition reactions by Co-catalyzed reductive coupling of organic tosylates and triflates with activated alkenes. Chem. Commun. 2017, 53, 11584-11587. [CrossRef] [PubMed]

74. Aizawa, S.-I.; Fukumoto, K.; Kawamoto, T. Effect of phosphine and phosphine sulfide ligands on the cobalt-catalyzed reductive coupling of 2-iodobutane with n-butyl acrylate. Polyhedron 2013, 62, 37-41. [CrossRef]

75. Lu, S.; Jin, T.; Bao, M.; Yamamoto, Y. Cobalt-catalyzed hydroalkylation of [60] fullerene with active alkyl bromides: Selective synthesis of monoalkylated fullerenes. J. Am. Chem. Soc. 2011, 133, 12842-12848. [CrossRef] 
76. Amatore, M.; Gosmini, C. Direct cobalt-catalyzed conjugate addition of functionalized aryl halides and triflates: A new strategy for the conjugate addition onto methyl vinyl ketone. Synlett 2009, 2009, 1073-1076. [CrossRef]

77. Qian, Q.; Zang, Z.; Chen, Y.; Tong, W.; Gong, H. Nickel and cobalt-catalyzed coupling of alkyl halides with alkenes via Heck reactions and radical conjugate addition. Mini-Rev. Med. Chem. 2013, 13, 802-813. [CrossRef] [PubMed]

78. Shukla, P.; Sharma, A.; Pallavi, B.; Cheng, C.-H. Nickel-catalyzed reductive Heck type coupling of saturated alkyl halides with acrylates and oxabenzonorbornadiene. Tetrahedron 2015, 71, 2260-2266. [CrossRef]

79. Shrestha, R.; Weix, D.J. Reductive conjugate addition of haloalkanes to enones to form silyl Enol ethers. Org. Lett. 2011, 13, 2766-2769. [CrossRef]

80. Shrestha, R.; Dorn, S.C.M.; Weix, D.J. Nickel-catalyzed reductive conjugate addition to enones via allylnickel intermediates. J. Am. Chem. Soc. 2013, 135, 751-762. [CrossRef]

81. Shen, Z.-L.; Cheong, H.-L.; Loh, T.-P. Indium/copper-mediated conjugate addition of unactivated alkyl iodides to $\alpha, \beta$-unsaturated carbonyl compounds in water. Tetrahedron Lett. 2009, 50, 1051-1054. [CrossRef]

82. Fleming, F.F.; Gudipati, S. Alkenenitriles: $\mathrm{Zn}-\mathrm{Cu}$ promoted conjugate additions of alkyl iodides in water. Org. Lett. 2006, 8, 1557-1559. [CrossRef] [PubMed]

83. Zhou, F.; Hu, X.; Zhang, W.; Li, C.-J. Direct conjugate additions using aryl and alkyl organic halides in air and water. Org. Chem. Front. 2018, 5, 3579-3584. [CrossRef]

84. Zhou, F.; Hu, X.; Zhang, W.; Li, C.-J. Copper-catalyzed radical reductive arylation of styrenes with aryl iodides mediated by zinc in water. J. Org. Chem. 2018, 83, 7416-7422. [CrossRef]

85. Lipshutz, B.H.; Huang, S.; Leong, W.W.Y.; Zhong, G.; Isley, N.A. C-C bond formation via copper-catalyzed conjugate addition reactions to enones in water at room temperature. J. Am. Chem. Soc. 2012, 134, 19985-19988. [CrossRef] [PubMed]

86. Fleming, F.F.; Gudipati, S.; Aitken, J.A. Alkenenitriles: Conjugate additions of alkyl iodides with a silica-supported zinc-copper matrix in water. J. Org. Chem. 2007, 72, 6961-6969. [CrossRef]

87. Streuff, J.; Gansäuer, A. Metal-catalyzed $\beta$-functionalization of Michael acceptors through reductive radical addition reactions. Angew. Chem. Int. Ed. 2015, 54, 14232-14242. [CrossRef]

88. Pang, H.; Wang, Y.; Gallou, F.; Lipshutz, B.H. Fe-catalyzed reductive couplings of terminal (hetero)aryl alkenes and alkyl halides under aqueous micellar conditions. J. Am. Chem. Soc. 2019, 141, 17117-17124. [CrossRef]

89. Hung, T.-T.; Huang, C.-M.; Tsai, F.-Y. Sonogashira-Hagihara coupling towards diaryl alkynes catalyzed by $\mathrm{FeCl}_{3} \cdot 6 \mathrm{H}_{2} \mathrm{O}$ /cationic 2,2'-bipyridyl. Chem CatChem 2012, 4, 540-545. [CrossRef]

90. Buchwald, S.L.; Bolm, C. On the role of metal contaminants in catalyses with $\mathrm{FeCl}_{3}$. Angew. Chem. Int. Ed. 2009, 48, 5586-5587. [CrossRef]

91. Zhou, F.; Li, C.-J. The Barbier-Grignard-type arylation of aldehydes using unactivated aryl iodides in water. Nat. Commun. 2014, 5, 4254. [CrossRef]

92. Wu, W.-Y.; Chen, S.-N.; Tsai, F.-Y. Recyclable and highly active cationic 2,2'-bipyridyl palladium(II) catalyst for Suzuki cross-coupling reaction in water. Tetrahedron Lett. 2006, 47, 9267-9270. [CrossRef]

93. Chen, S.-N.; Wu, W.-Y.; Tsai, F.-Y. Hiyama reaction of aryl bromides with arylsiloxanes catalyzed by a reusable palladium(II)/cationic bipyridyl system in water. Tetrahedron 2008, 64, 8164-8168. [CrossRef]

Publisher's Note: MDPI stays neutral with regard to jurisdictional claims in published maps and institutional affiliations.

(C) 2020 by the authors. Licensee MDPI, Basel, Switzerland. This article is an open access article distributed under the terms and conditions of the Creative Commons Attribution (CC BY) license (http://creativecommons.org/licenses/by/4.0/). 